\title{
AN APPROACH TO DEVELOP A MOTION-SENSITIVE, LOCALLY MULTIPLAYER- HYBRID (MULTIPID) 3D VIDEO GAME
}

\author{
Gizem Kayar*, Department of Computer Engineering, TED University, Turkey, gizem.kayar@tedu.edu.tr \\ (https:// Dorcid.org/0000-0002-7811-9357)
}

Received: 03.02.2019, Accepted: 19.04.2019

Research Article

*Corresponding author

DOI: $10.22531 /$ muglajsci.521585

\begin{abstract}
Playing video games has been gaining increased interest over the last two decades regardless of age, gender and any kind of status. Video games are generally controlled via frequently used input devices such as game controllers or mouse and keyboard. However, there are also newer technologies which can detect human motion through sensors. This technology enhances the game-play experience due to its interactivity level and therefore, such an experience embraces many players more than traditional controllers. The term "Hybrid" is used for both the multi-genre games and for games integrating conventional controllers together with new technology devices, e.g. motion-sensitive devices. In this paper, we use the term for the latter. Our aim is to provide the game developers a roadmap to generate a $3 D$ hybrid game in order to enhance the game-play experience where we mainly control the game with keyboard but also integrate Kinect to sense human motion and solve interactive puzzles at the end of each level. Besides, we also suggest to enable the multiplayer mode for some interactive puzzles to challenge the players and observe their contentedness in terms of game-play. After this experience, we named this game model as MultipId game-model as it combines the features of both Multiplayer and Hybrid modes. We developed a game employing this model and conducted a user study which is discussed in the Results section. When we asked the players, more than 60\% have stated that Kinect-based local multiplayer sub-sections improve the engagement of game quite effectively. Besides, $87 \%$ of the attendees stated that they like to see more MultipId games in the market. We believe that increasing the number of MultipId games gives a competitive edge over existing single-player games that employ only traditional controllers.
\end{abstract}

Keywords: Game Engine, Kinect, Unity, Hybrid Game, Game Development, Multiplayer Games

\section{HAREKETE DUYARLI, LOKAL ÇOK OYUNCULU-MELEZ(MULTIPID) 3B VIDEO OYUNU GELIŞTİRME IÇCíN BİR YAKLAŞIM MODELİ}

\section{Özet}

Video oyunlarına olan ilgi, geçtiğimiz 20 sene içerisinde, yaș, cinsiyet ve sosyal statüye bakmaksızın hergün daha fazla artmıştır. Video oyunları genelde sıklıkla kullanılan giriş aygıtları olan oyun kumandaları ya da klavye ve fare ile oynanmaktadır. Ancak, insan hareketlerini sensörler vasitasi ile algilayabilen daha yeni teknolojiler mevcuttur. Bu teknoloji, interaktivite seviyesine bağlı olarak oyunlarda oynanma deneyimini artırmaktadır ve bu sebeple pek çok oyuncuya geleneksel oyun kumandalarından daha cazip gelmektedir. "Melez" kelimesi oyun sektöründe hem çoklu türdeki oyunları, hem de geleneksel oyun kumandaları ve yeni teknoloji aygıtları, ör. hareket-algılayıcllar, birlikte entegre etmis oyunları ifade etmekte kullanılır. Biz çalışmamızda melez dediğimizde ikinci yaklaşımı kullanıyor olacağız. Amacımız, oyun oynanma deneyimini artırmak adına oyun geliștiricilerinin temelde geleneksel oyun kumandaları ile oynanan ancak her seviyede oynayıcı hareketlerini algılayıp interaktif oyunlar oynamasını sağlayan melez oyun üretmeleri adına bir yöntem sunmaktır. Ayrıca, çoklu-oyuncu mod desteği ile oyuncuların rekabet edebilecekleri interaktif oyunlar eklemeyi ve oyuncuların bu oyunlardaki memnuniyet oranını gözlemlemeyi de öneriyoruz. Bu deneyim sonrasında, bu oyun modelimize Çoklu-Oyun ve Melez kelimelerinin İngilizce karşılıklarının birleşmeleri ile oluşan MultipId oyun modeli kısa adını vermiş bulunmaktayız. Bahsettiğimiz modelimiz ile geliştirdiğimiz örnek oyun ve yürüttüğümüz anket çalışması, Sonuç kısmında anlatılmaktadır. Oyunumuzu oynayan katılımcıların en az yüzde 60’ı Kinect tabanlı lokal çoklu-oyuncu destekli ara bölümlerin, oyun oynama deneyimini artıracağını belirtmiştir. Ayrıca, katılımcılarımızın yüzde 87'si pazarda daha fazla MultipId oyun görmek istediklerini belirtmişlerdir. Inanıyoruz ki MultipId oyun sayısını artırmak, var olan tek-oyunculu geleneksel giriş aygıtları ile oynanan oyunlar ile kıyaslandığı zaman rekabeti artıracak bir çizgi oluşturacaktır.

Anahtar Kelimeler: Oyun Motoru, Kinect, Unity, Melez Oyun, Oyun Geliştirme, Çoklu-Oyunculu Oyun

Cite

Kayar, G., (2019). “An Approach To Develop A Motion-Sensitive, Locally Multiplayer-Hybrid (Multipid) 3d Video Game”, Mugla Journal of Science and Technology, 5(1),105-113. 


\section{Introduction}

Video game industry is one of the biggest economic sectors all over the world with estimated $\$ 137.9$ billion revenue in 2018 over $50 \%$ mobile, $25 \%$ console and $24 \%$ PC games, according to Newzoo [1]. Video gaming trend accelerates everyday as engagement grows with millions of people over different countries. This situation causes the sector grow much faster. Today, Game Market's top 3 countries are China, U.S. and Japan [2-4] (for details, please see Figure 1). Turkey was also well known in the market of 2017 not only with its 30.8 million active gamers and \$773.9M total revenue (rank: 18 [5]), but also with its productive game development companies. For instance, in 2018, Zynga, one of the leading social game development companies worldwide, acquired Turkish game developing company Gram Games for $\$ 250$ million in cash [6]. The reason is, Gram Games team's effective and profitability costs (they produced more than 170 million times downloaded hyper-casual and puzzle games), match with Zynga's long-term growth plans. Once again, this sale showed the power of game industry and how game development companies invest on future. Those who are interested can also see the "Digital Game Sector Report" prepared by Ankara Development Agency [7], and also other valuable publications, e.g. [8-10], that discuss the video game industry in Turkey.

While still most of the revenue is obtained over casual, hyper-casual or social mobile games; expanding video quality, increasing the performance in terms of physically-based computations, integration of virtual/augmented reality and detecting human-motion through sensor technologies accurately are still some of the main focuses of researchers.

Motion detection refers to the process of detecting the changing positions of moving objects relative to its environment and other static or dynamic objects in a reasonable region. There are different sensing technologies used for this aim, e.g. infrared, optics, RFE, sound, etc. Using motion controllers became popular in 2006 when Wii Remote motion controller came to market. This accelerometer based motion detection technology was able to approximate the orientation of the player and this enabled the player's movement be considered as the input of the game. Later, other 7 th and 8th generation game consoles started to use similar technologies. In 2010, Sony launched PS Move to market which is also a controller with magnetometers that track Earth magnetic field and track location using PS Eye. There are many other motion controllers similarly launched to market. The detailed explanation of motion controllers is beyond the scope of this paper. For details, please see [11]. Different than this controller/handler technology, Microsoft introduced web-cam styled Kinect

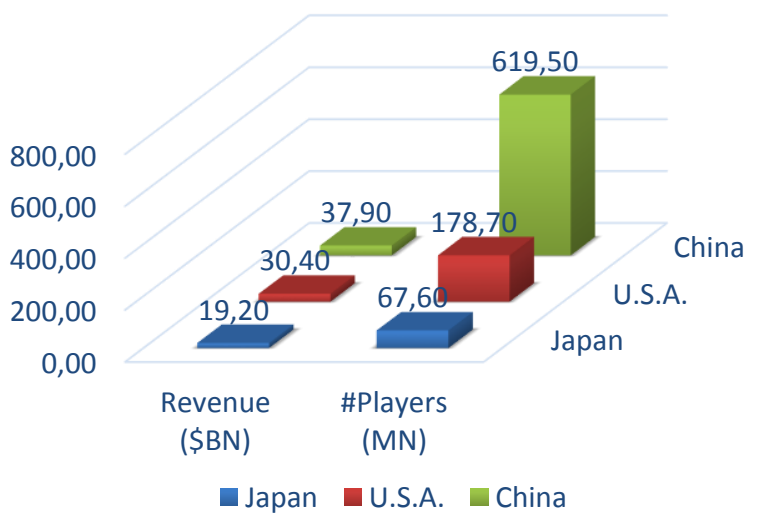

Figure 1: Top 3 countries in Gamer Market with their expected total revenue given in billion dollars and number of players in millions according to Newzoo reports $[2,3,4]$.

as a motion sensing input device in 2010 which has been preferred by many gamers since then due to its flexibility with controller-free technology, easily adaptable multiplayer mode (only one Kinect is enough for multiple players) and its accuracy in motion sensing. This flexibility and accuracy made Kinect be used in many other fields, e.g. healthcare games and platforms (e.g. [12-14]), computer vision, robotics (e.g. [15-17]) or educational purposes (e.g. [18-20]).

With the increased interest in video games, companies started to launch new game engines in the market. Unity has been amongst the most popular cross-platform game engines with its free edition and low learning curve since it was introduced in 2005. Due to the fact that the popularity of games with motion sensing technologies started to increase, game engines started to work on the integration of this technology into their systems. Since then, Unity has always been one of the most frequently investigated cross-platform game engines for Kinect integration.

Our contribution. When we considered the nocontroller flexibility, freely coming multiplayer mode and high motion tracking accuracy of Kinect and the ease of its adaptability with Unity, we preferred to use Kinect and Unity for our project. Our aim here is to give a different touch to a conventional keyboard-input 3D PC video games as we add single or sometimes multiplayer mode enabled interactive Kinect puzzles at each level, and explain the methods to solve encountered problems. MultipId keyword is used as the abbreviation of our hybrid model in this work. We also conducted a survey to measure the players' contentedness in our proposed game.

\section{Related Work}

\subsection{Game Experience}

It is a well-known issue that poorly analyzed game requirements and poorly designed games reduce the game-play satisfaction of gamers. Requirements 
engineering can step in at the very beginning of game development in order to avoid the application of fixes that causes serious problems in later phases. User satisfaction surveys are one of the key solutions in game engineering to prevent such problems. Paschali et al. discuss such non-functional requirements in [21] where they evaluate the correlation between different satisfaction factors, e.g. scenario, controls, graphics, sound, speed and community as they also discuss these factors over various genres. In [22], Saenz-de-Urturi et al. discusses the difficulties of game playability for elderly people and how to ameliorate the conditions for them by making observations. Another study about the evaluation of games was run by Mayer et al. [23], where they analyze the requirements of generating simulation games and evaluate the results. El-Nasr and Yan [24] discusses the factors to improve the game level design and graphics of games by observing players' visual attention patterns in 3D game environments using an eye tracker and they arrive at interesting conclusions for different game genres.

We also see other related work in the literature which discuss game experience related issues in terms of Kinect-like motion sensing game input environments. For instance in [25], a systematic review is done by Simor et al. to evaluate the usability of gestural interaction over different works. In [26], Bampatzia et al. evaluate player experience by comparing game input modalities. For this comparison, they propose to use one conventional input device, which is a mouse in this case, and a new technology motion sensing device which is Kinect. In this work, they conclude that Kinect users report being happier and more self-esteemed after playing the game compared to mouse users. The authors also state that Kinect users report higher satisfaction and more engagement. Liao and Long also claim a similar result saying that gestural user interfaces can increase immersion and improve user experience [27]. The study of Bampatzia et al. [26] was one of our starting points while choosing to work on such a game type.

\subsection{Games with Different Input Devices}

With the rapid development of technological input devices, head-mounted displays, e.g. VR devices such as Occulus Rift or HTC Vive, motion-tracking or gesturecontrolled technologies, e.g. Kinect, Leap Motion, etc., and even motion platforms, e.g. Virtuix Omni, have started to be integrated in video games much more frequently. As this trend started to grow, it has started to become a more permanent research area. In [28], Lee et al. explains how to utilize several input devices in a video game, and in [29], the same group explains a development method of a VR game utilizing Kinect and Oculus Rift that will be adapted for a smartphone.

There are many publications also on gesture-controller technology, e.g. Leap Motion [30], which supports hand and finger motions as input. In [31], Pirker et al. explores Leap Motion for computer games. The authors state that while the suitability for traditional video games is thus described as limited, users see potential in gesture-based controls as training and rehabilitation tools. In [32], Krastev et al. uses Leap Motion for a 2D game rather than a 3D one and presents the overall design and implementation of the game. In [33], Panat et al. explains the importance of Leap Motion on game-based learning.

As an alternative approach, the player can move in a limited real world space using "treadmill" systems, e.g. Virtuix Omni [34]. These systems are still high-cost but increases the game experience and takes it one step further. For more details, one can check [35].

Although it is not easy to find a multiplayer hybrid game which is playable not with a single input device but with more than one, Ryse [36] can be given as an example. Ryse is the first hybrid game that is playable with Xbox 360 controller and Kinect, and was developed by Crytek [37] which is a Germany-based video game development company founded by Turkish brothers Cevat, Avni and Faruk Yerli in 1999. Since then, Crytek produced several of the most prestigious games of the game industry, e.g. Crysis series, using their own game engine. The Ryse game features Kinect voice integration, in which players can give commands to other characters to call in arrows or catapults. According to the creators of the game [38], the team had developed three prototypes for the game. In the first one, entire game is played with Kinect, the second one integrates Xbox 360 controller, with Kinect features, while the third one completely removed the Kinect. Later, Crytek decided to go with the second prototype.

We also adopted a similar idea in our game. We think that playing the entire game in Kinect mode is a tiring experience for such kind of long-play games. However, adding features of Kinect enhances the gameplay experience. Besides, the industry is still in the beginning of developing hybrid games and it is not easy to find such games for those who are interested. This is the motivation that directs us to create a hybrid game.

There are still many issues related to game development which are open research areas, e.g. "game based learning", "artificial intelligence", "social impact of gaming", "networking" and "graphics algorithms". However, they are beyond the scope of this paper. For those who are interested, we can suggest the work of Ampatzoglou and Stamelos [39].

\section{Implementation}

Game development can be considered as a type of software development project which is composed of several important stages, e.g. pitch, game design, 


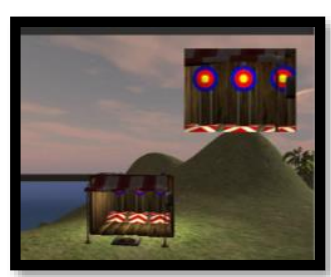

(a)

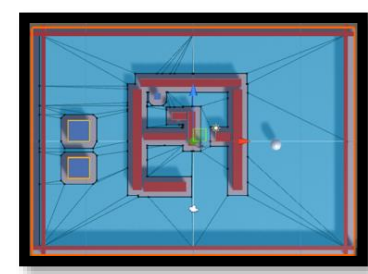

(b)
Figure 2: a) A minimap from [42] b) A labyrinth scene we generated using Unity Navmesh system for AI agents.

production with programming, level, art and audio design sub-stages, and testing. Compared to other software design processes, game design can be considered as agile development rather than conventional software life cycle models, e.g. waterfall model [40]. In large projects, all of these stages employ many different professionals, e.g. game designer, level designer, concept artist for 2D/3D artwork creation and sketches, drafts, modeler, animator, programmer for, e.g. physic, AI, gameplay, UI editor, network, tester and finally a project manager. However, in smaller projects, the programmer generally develops whole stages on her/his own by getting some outside help for art or models. Here, for those who do not use any 2D/3D modeling tool and sketch tools, we suggest to use free assets that can be found in Unity asset store [41].

According to our previous experiences, we defined the basic eight requirements of a video game as:

1. Minimum system requirements should be acceptable and cost-effective

2. Game should not be too complicated however should have a continuous challenge/reward system and an interesting storyline

3. It should have a straight and funny game-play with different difficulty options, and direct the user using tips, minimap/radars (see Fig. 2-a), etc.

4. Game states should be saved and loaded in a fast manner

5. The game should have different visual setup options, e.g. resolution, model quality, lighting conditions, lightmaps, shadow conditions

6. Models, characters and sounds should be catchy

7. 3D models should consider level-of-detail (LOD) concept in order to prevent more hardware power usage

8. Testing process should be thorough

Any game without above given properties can be considered unsuccessful in today's game world. Even though "Video Game Design and Programming" related publications are still very limited in today's world and articles are generally web-based, we have deduced above points with respect to our own experiences and observations together with these resources, e.g., [44-47] that discuss some of these points. Therefore, we took these points into consideration. Of course there are more advanced settings that can be integrated in games, e.g. AI agents (see Fig. 2-b). We propose to create intelligent enemies for more realistic combat scenes.

Regarding the multiplayer games, one should be aware of the difficulties in development. Nowadays, when gamers talk about multiplayer games, they generally mean online games during whose production a network programmer should be very careful. Today's technology allows many people to use advanced networking technology to play together over a great distance. This is the same technology that allows to develop massively multiplayer online games (MMOG) and allow players play their games without time delay. For instance, Ryse is a traditional multiplayer game. However, multiplayer word is also used for locally played games, too. Different than classical multiplayer games as in Ryse, we propose to enable multiplayer mode locally and only for Kinect puzzles at the end of the stages for small projects. By this way, a small team of programmers will not spend time on efficient network programming but also give the players a taste of multi-playing mode.

Therefore, in addition to eight requirements we have given before, we can add the requirements of a hybrid, locally multiplayer Kinect game as:

- A large enough tracking area for Kinect in order to allow more efficient motion tracking of two players

- Multiplayer tracking integrity of Kinect and Unity

- Zero necessity for Internet connection

- Additional testing for Kinect and multiplayer mode

\section{Kinect Integration and Testing:}

In order to communicate with Kinect sensor, one needs Kinect SDK and a HDMI cable. Kinect package takes the Kinect data - human motion - from sensors and converts it to character movements for Unity. It can convert and use up to two characters at the same time which also allowed us to generate our game. There are couple of Kinect SDKs which are compatible with Unity. One example is given in Figure 3.

Kinect skeleton data has 25 joints (see Figure 4). Our suggestion is to track and analyze these joints and their movements thoroughly. There are many researchers who apply machine learning algorithms on Kinect data for pose and gesture classification, e.g. [48, 49]. Since Kinect V1 cannot detect finer movements and motion capture is still not $100 \%$ accurate, applying learning algorithms can ameliorate the results. However, since our research focus is not machine learning, we directly used our raw Kinect data. 


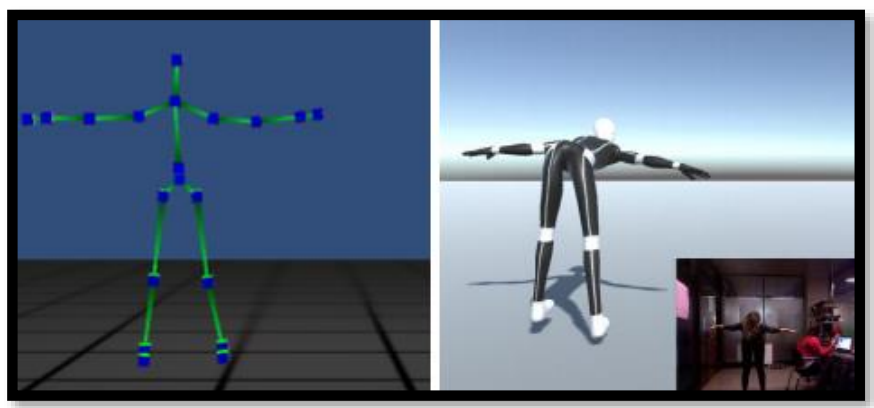

Figure 3: Kinect Mocap Animator [43] while being used by one of our teams. This tool records user motions as .fbx animation clips. On the left, the created cube man is shown from one of our scenes. On the right, tracked human motion is converted to character movement.

Movements: In order to give walk and run movements to the characters in a limited room space, some people use treadmill systems, e.g. Virtuix Omni [34]. Due to the fact that we do not have such a system, we applied a simple equation in our program. Therefore, if Equation (1) holds, this means that our character is walking or running.

$$
\left[k j p_{t 1}-k j p_{t 0}\right]>\text { threshold }
$$

where kjp stands for knee joint positon, $t_{1}$ and $t_{0}$ are subsequent real timesteps in the game and threshold is an empirical distance we decide according to the height of the player. Speed of movement can be checked to apply the same idea to running instead of walking.

A similar idea is also applicable for aiming the gun to the enemy. This time, the wrist position in the Kinect skeleton has to be checked to track the raise of it (please see Equation (2) for the aim condition). Whenever a raise is detected, a shot can be sent to the enemy. The frequency of these shots are totally up to programmers.

$$
[w j p-h j p]<\frac{h l g}{3}
$$

In (2), wjp stands for wrist joint position, hjp for head joint position and $h l g$ for approximate head length found using head and neck joints. Our parameter setup is empirical and they are adaptable to different users.

Enemy-contact (combat): Other than walking, running and gun aiming, enemy-contact can be resolved by inserting colliders around joints and checking whether the collider of enemy is in our trigger area or not with respect to world coordinates. Unity provides different collider mechanisms for this purpose.

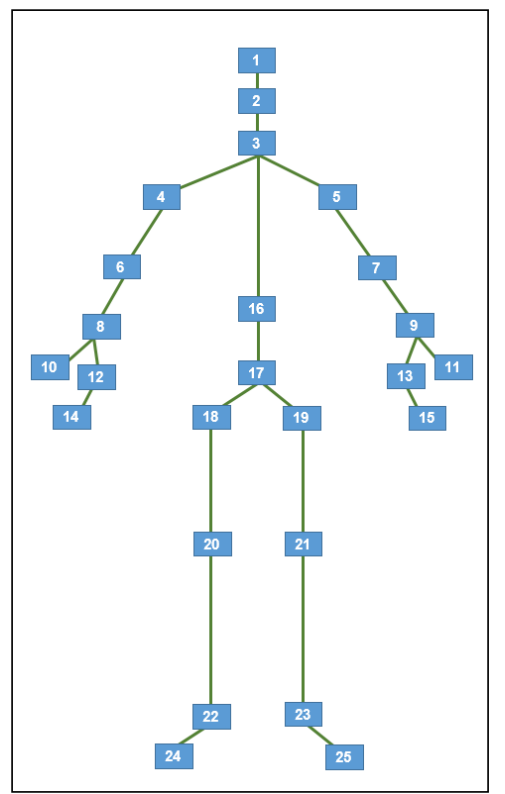

Figure 4: Kinect Joints on cubeman skeleton. 1-head, 2-neck, 3-spine shoulder, 4-shoulder left, 5-shoulder right, 6-elbow left, 7-elbow right, 8-wrist left, 9-wrist right, 10-thumb left, 11-thumb right, 12-hand left, 13hand right, 14-hand tip left, 15-hand tip right, 16-spine mid, 17-spine base, 18-hip left, 19-hip right, 20-knee left, 21-knee right, 22-ankle left, 23-ankle right, 24foot left, 25-foot right

\section{Results}

We developed a survival game (Figure 5) in which our character is trying to escape enemy characters by either walking or by driving and trying to solve the puzzles using Kinect technology to pass each level. The game was developed using Unity v5.5 in Windows 10 with C\# scripting language with a team of two programmers in 6 months period. In terms of hardware, we had Core i5 Processor, 8GB RAM with GTX 950M graphics card in our workstation and used XBOX 360 Kinect v1.

Since our team does not have a 3D modeler, animator or sound designer, we took the advantage of using Unity Asset Store, e.g. city packs, car pack, weapon pack, character pack and sound pack, since creating these 3D models and sounds is not related to our research.

What we tested mainly can be found below:

- functionality

- mechanics: character, Kinect sensor, car

$\circ \quad$ AI agents

○ menu items

- save state and reload

- performance

We have seen that using the approach described above, a small team can develop a game with properly working 


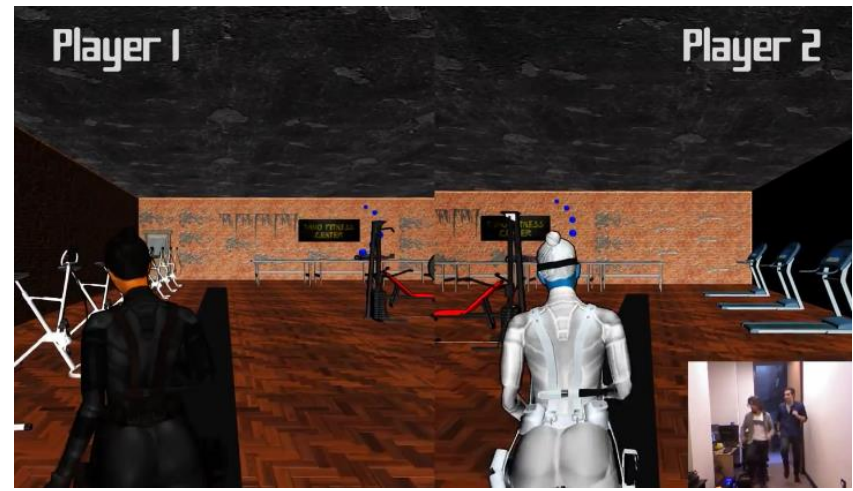

Figure 5: Multi-player mode is on for one of our quiz scenes. Both players try to access the wall by running.

mechanics and interesting multi-player mode to enhance the gameplay in a period of couple of months.

In terms of performance, even our hardware support was not very advanced, we always observed at least 30 frames per second (fps) which is suitable for human-eye and still seen in many popular video games. FPS was higher for our other test machines with Core i7 Processor, 16GB RAM and GTX 970M or GTX 1060 graphics card.

In order to support our initial claim, we have ended our work with an experimental study on a group of 23 active game players / game programmers. $22 \%$ of the respondents are female, whereas $78 \%$ of the group are male. $26 \%$ of the respondents are in the age group of 21 22 whereas other respondents are in the range of 23-24. All respondents played the game in the same room under the same conditions. According to the results, we have seen that:

- $13 \%$ of the respondents prefer console games, $8 \%$ prefer mobile games whereas $79 \%$ of the group prefer PC games.

- $\quad 22 \%$ of our group prefers single player games whereas, 9\% prefer MMOG (massively multiplayer online games) and 69\% prefer playing multi-player games.

- More than $50 \%$ of the respondents play games actively every day and $26 \%$ of them play games at least 2-3 times a week.

- When we asked the players how interested they are in Kinect games (rates are in [1-5] range), $56 \%$ rated at least 4 whereas the rest is divided almost equally in other range elements.

- The $50 \%$ of the respondents rated their motivation during the gameplay as 5 (the max. value in [1-5] range), $35 \%$ as 4 and $15 \%$ as 3 where there was nobody rated their motivation as 1 or 2 .

These initial findings show that our survey group is quite suitable for our study. In addition, we have asked the respondents how they see themselves and which genres they like most to give our readers a better idea. The results can be found in Figure 6 .
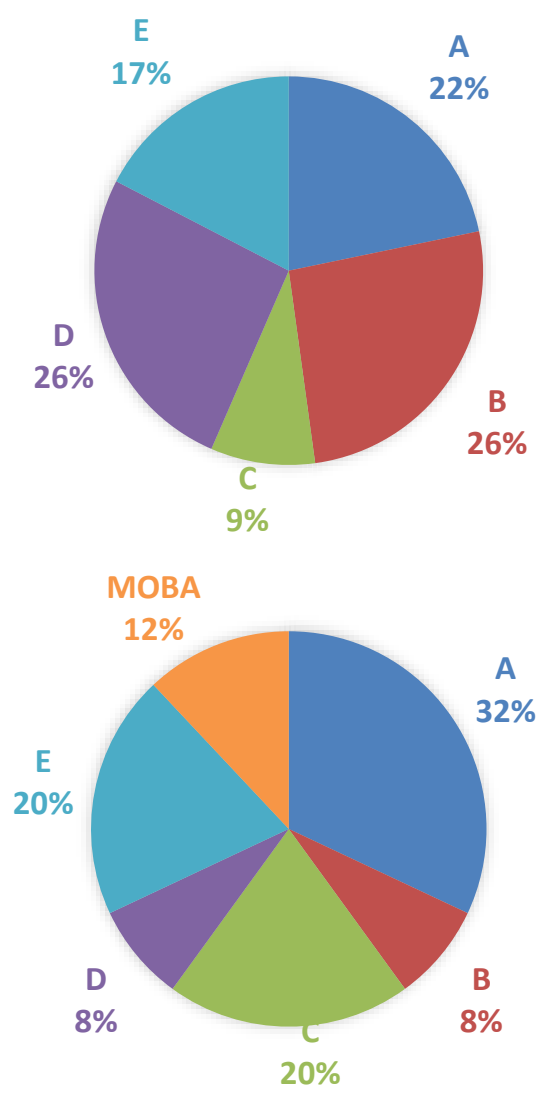

Figure 6: Top - Gamer type: How respondents see themselves. A stands for "I consider myself a gamer and willing to spend on games", B for "I am a game enthusiast and play often, spending on games suits me", C for "I am a gamer for exercise and I do not spend too much on games", D for "I like the social aspect of games, I play with family or friends" and E for "I play because I like competition". Bottom - Genres: A stands for "Action", B for "Adventure", C for "Role Playing Games", D for "Sports", E for "Strategy" and MOBA for "Multiplayer online battle arena".

In the second part of our survey, we have asked the users the following questions and obtained the following results. In order to estimate the central tendency, we share the mean and median together with the standard deviation of our data.

-If you have chosen $A$ for question 6 (means prefer single-player games) and A, B or C for question 7 (means plays games at least once in 2-3 days or everyday), do you think that this situation affects your social life in negative way? On a scale 1 (least) to 5 (most), how interested are you in playing Multipld games to ameliorate this situation? 
- $72 \%$ of the respondents who answered this question gave 3 or more points to this question. Mean: 3, Median: 3, standard deviation: 1.18.

-To what extent did you find MultipId game more engaging when compared to non-Kinect based multiplayer online games -- 1(least) to 5 (most)?

- Only $20 \%$ of the respondents rated 1 and 2 in this question where $80 \%$ of the respondents rated at least 3. Mean: 3.22, Median: 3, standard deviation: 1.08 .

-To what extent did you find MultipId game more engaging when compared to single-player games 1 (least) to 5 (most)?

- $65 \%$ of the respondents rated at least 4 where the majority resides in rate 5. Mean: 3.7, Median: 4, standard deviation: 1.26 .

-How much would you say you enjoyed playing the game -- 1(least) to 5 (most)?

- $80 \%$ of the respondents rated at least 4 in this question. Mean: 4.1, Median: 4, standard deviation: 1.04

Finally, we asked the respondents about the multiplayer subsections and the market potential of the game. The results can be seen in Figure 7 . We believe that this survey is a good indicator about the potential of MultipId games. The survey shows that majority of the players believe in the potential of MultipId games, its engagement capacity, power in enhancing gameplay and also its market potential. Our survey's raw data and HREC approval can be found under: https://www.dropbox.com/sh/yd36w52oc268ldr/AAC GjUgxlQx4PGNJLGFCseRja?dl=0

\section{Conclusion and Future Work}

We have presented an approach to develop a motionsensitive, locally multiplayer-hybrid 3D video game which we name as MultipId. We have proposed a method to accomplish such a work in a small team of programmers. After our observations on the players, we can state that the number of MultipId games can give a competitive edge over existing single-player games employing only traditional controllers. Our results show that such a game with locally multiplayer Kinect mode enhances the gameplay in a positive way. When we asked the players, more than $60 \%$ have stated that Kinect-based local multiplayer sub-sections improve the engagement of game quite effectively. Besides, $87 \%$ of the attendees stated that they like to see more MultipId games in the market.

This approach can be quite interesting for start-up companies whose concern is quick game development by employing small number of programmers and content creation artists. The idea can be interesting for also
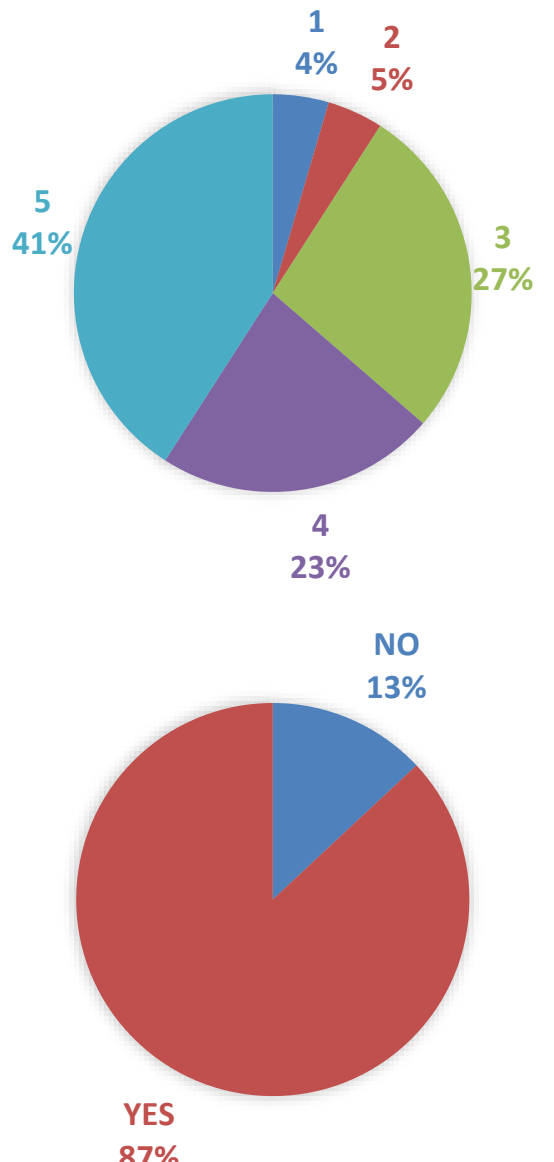

Figure 7: Top: To what extent did you think integrating Kinect-based local multiplayer subsections improve the engagement of game -- 1(least) to 5 (most). Bottom: Would you like to see more MultipId games in the market?

large-scale companies due to the fact that since the development of Ryse, the hybrid games is hardly found in the market.

Our purpose in this study was to observe the players' integrity in such a game environment. Therefore, all attendees have played the same game under the same physical conditions. We did not use a control group. In the future, we plan to observe the differences in between a standard group who play with all the capabilities of the game and a control group who are using no motion sensing devices. Since we have developed a specific game type with its own attributes, we have created our own survey to measure user satisfaction. In our next study, we plan to use one or more of the popular engagement scales, e.g. Immersive Experience Questionnaire IEQ, Game Engagement Questionnaire GEQ/GEngQ, and Player Experience of Need Satisfaction PENS scale in addition to our own questionnaire. We believe that meaningful data can be obtained also from such a study. 
Another direction can be to improve motion sensing devices. Kinect v1 cannot detect small joint movements, e.g. fingers, appropriately. For more accurate motion tracking, Kinect v2 or Leap Motion can be used in the future to develop more quizzes employing hand gestures.

Finally, it is an exciting outlook to integrate virtual reality head-sets into our game during puzzle sessions in order to increase the engagement of the player.

\section{Acknowledgements}

We thank the reviewers for their helpful comments, Berk Cebeci and Kemal Çağlar Güler for their effort and Dr. Selen Pehlivan for her helpful thoughts throughout the project. This project was partly supported by TED University Undergraduate Research Fund (TEDU URF - Project No: OURF16B0002). The conducted survey has been evaluated by TEDU Human Research Ethical Committee (HREC) and received approval on 20.02.2019 with 2019/03 decision id.

\section{References}

[1] Newzoo. "Mobile Revenues Account for More Than 50\% of the Global Games Market as It Reaches \$137.9 Billion in 2018". https://newzoo.com/insights/articles/globalgames-market-reaches-137-9-billion-in-2018-mobilegames-take-half/ (14.09.2018).

[2] Newzoo. "China's Games Market". https://newzoo.com/insights/infographics/china-gamesmarket-2018/ (14.09.2018).

[3] Newzoo. "U.S.' Games Market". https://newzoo.com/insights/infographics/us-gamesmarket-2018/ (14.09.2018).

[4] Newzoo. "Japan's Games Market". https://newzoo.com/insights/infographics/japan-gamesmarket-2018/ (14.09.2018).

[5] Newzoo. "The Turkish Gamer". https://newzoo.com/insights/infographics/the-turkishgamer-2017/ (14.09.2018).

[6] Zynga. "Zynga Acquires Leading Global Mobile Game Developer Gram Games; Team Behind Hit Titles Merge Dragons! and 1010!". http://investor.zynga.com/newsreleases/news-release-details/zynga-acquires-leadingglobal-mobile-game-developer-gram-games (14.09.2018).

[7] Ankara Development Agency. "Dijital Oyun Sektörü Raporu”. Ankara, Türkiye, 01.12.2016.

[8] Yilmaz, E., Cagiltay, K. "History of Digital Games in Turkey". In DiGRA Conference. June, 2005.

[9] Şengün, S. "A Survey of Marketing Management for the Video Games Industry in Turkey". In Marketing Management in Turkey (pp. 353-387). Emerald Publishing Limited. 2018.

[10] Tuker, C., Yilmaz, E., \& Cagiltay, K. "Video Games Around the World (Turkey)”. In M.J.P. Wolf \& T. Iwatani (Ed.), Video Games Around the World (565-578). Cambridge, MA: MIT Press. 2015.

[11] Landerholm, M. Motion Controllers for Game Consoles. MSc Thesis. KTH CSC Royal Institute of Technology. Stockholm, Sweden, 2011.

[12] Dove, E., Astell, AJ. "The Use of Motion-Based Technology for People Living With Dementia or Mild Cognitive
Impairment: A Literature Review“. Journal of Medical Internet Research. 19(1), 2017.

[13] Brown, JS. Pilot Study of a Kinect-Based Video Game to Improve Physical Therapy Treatment. MSc Thesis. Purdue University, West Lafayette, U.S.A, 2013.

[14] Popolizio, SD., Loman, J., Cordes, CC. “Comparing Outcomes of Kinect Videogame-Based Occupational/Physical Therapy Versus Usual Care“. GAMES FOR HEALTH JOURNAL: Research, Development, and Clinical Applications. 3(3), 157-161, 2014.

[15] Kvalbein, M. The Use of a 3D sensor (Kinect) for Robot Motion Compensation. MSc Thesis. University of Oslo, Oslo, Norway, 2012.

[16] El-laithy, RA., Huang, J., Yeh, M. "Study on the Use of Microsoft Kinect for Robotics Applications". Proceedings of the 2012 IEEE/ION Position, Location and Navigation Symposium, Fullerton, U.S.A., 2012.

[17] Han, J., Shao, L., Xu, D., Shotton, J. “Enhanced Computer Vision with Microsoft Kinect Sensor: A Review“. IEEE Transactions on Cybernatics, 43(5), 1318-1334, 2013.

[18] Maiga, C., Denis, L., Fuhua, L., Farook, A., Nian-Shing, C.. "Enhancing Orbital Physics Learning Performance through a Hands-on Kinect Game". TED EĞİTiM VE BILLIM. 40(180), 2015.

[19] Hsu, HMJ. "The Potential of Kinect in Education". International Journal of Information and Education Technology. 1(5), 2011.

[20] Xu, X., Ke, F., Huang, D. "Exploring the Embodied Interactive Learning Effects - Designing an Instructional Scenario with Unity3D and Kinect V2 Sensor". In Proceedings of EdMedia World Conference on Educational Media and Technology. Vancouver, BC, Canada: Association for the Advancement of Computing in Education (AACE). 1618-1623, 2016.

[21] Paschali, EP, Ampatzoglou, A., Chatzigeorgiou, A., Stamelos, I. "Non-functional requirements that influence gaming experience: a survey on gamers satisfaction factors". AcademicMindTrek '14 Proceedings of the 18th International Academic MindTrek Conference: Media Business, Management, Content \& Services, Tampere, Finland. 04-06 November 2014.

[22] Sáenz-de-Urturi, Z., Zapirain, BG., Zorrilla, AM. "Elderly user experience to improve a Kinect-based game playability“. Behaviour \& Information Technology. 34(11), 1040-1051, 2015.

[23] Mayer, I., Bekebrede, G., Harteveld, C., Warmelink, H., Zhou, Q., van Rujiven, T., Lo, J., Kortmann, R, Wenzler, I. "The research and evaluation of serious games: Toward a comprehensive methodology". British Journal of Educational Technology. 45(3), 502-527, 2014.

[24] El-Nasr, MS., Yan, S. "Visual Attention in 3D Video Games". ACM SIGCHI international Conference on Advances in Computer Entertainment Technology. Hollywood, USA. 14-16 June 2016.

[25] Simor, FW., Brum, MR., Ebertz, Schmidt. JD, Rieder, R, Bertoletti De Marchi, AC. "Usability Evaluation Methods for Gesture-Based Games: A Systematic Review“. JMIR Serious Games. 4(2), 2016.

[26] Bampatzia, S, Antoniu, A, Lepouras, G. "Comparing Game Input Modalities: A Study for the Evaluation of Player Experience by Measuring Self Reported Emotional States and Learning Outcomes“. 4th International Conference on Games and Learning Alliance. Rome, Italy. 09 - 11 December 2015.

[27] Liao, H, Long, X. "Study on virtual assembly system based on Kinect somatosensory interaction". International 
Conference on Information Science and Cloud Computing. Guangzhou, China, 7-8 December 2013.

[28] Lee, DI, Baek, KY, Lee, JH, Lim, H. "Game Development Utilizing Several Input Devices". Advanced Science and Technology Letters. 113, 134-139, 2015.

[29] Lee, DI, Baek, KY, Lee, JH, Lim, H. “A Development of Virtual Reality Game utilizing Kinect, Oculus Rift and Smartphone". International Journal of Applied Engineering Research. 11(2), 829-833, 2016.

[30] Leap. "Leap Motion". https://www.leapmotion.com/ (15.09.2018).

[31] Pirker, J, Pojer, M, Holzinger, A, Guetl C. "Gesture-Based Interactions in Video Games with the Leap Motion Controller". Conference: International Conference on Human-Computer Interaction, May, 2017.

[32] Krastev, G, Voinohovska, V, Tsankov, S, Dineva, V. "Controlling a 2D computer game with a Leap Motion". IOSR Journal of Computer Engineering (IOSR-JCE). 19(6) 81-93, 2017.

[33] Panat, A, Pandit, S, Inchanale, O, Pandey, V. "3D Game Based Learning by Using Leap Motion". International Journal of Innovative Research in Science, Engineering and Technology. 6(3), 3415- 3419, 2017.

[34] Virtuix. "Virtuix Omni”. http://www.virtuix.com/products (08.09.2018).

[35] Hilfert T, König M. "Low-cost virtual reality environment for engineering and construction". Visualization in Engineering. 4(2), 2016.

[36] Ryse. "Ryse - Son of Rome". https://www.crytek.com/games/ryse (10.09.2018).

[37] Crytek. "Crytek". https://www.crytek.com/ (10.09.2018).

[38] Ryse. "Ryse: Son of Rome". https://en.wikipedia.org/wiki/Ryse:_Son_of_Rome (10.09.2018).
[39] Ampatzoglou, A, Stamelos, I. "Software engineering research for computer games: A systematic review". Journal Information and Software Technology. 52(9), 888901, 2010

[40] Bates, B. Game Design 2nd ed. Thomson Course Technology. ISBN 1-59200-493-8 2004.

[41] Unity. "Unity Asset Store". https://assetstore.unity.com/ (10.09.2018).

[42] Goldstone, W. Unity 3.x Game Development Essentials. Packt Publishing. Kindle Edition. (10.03.2017).

[43] Filkov, R. "Kinect Mocap Animator." https://rfilkov.com/2015/12/26/kinect-v2-mocapanimator/ (18.12.2017)

[44] Good Game 1. "What makes a good computer game?" https://www.bbc.com/bitesize/articles/zw96tfr (02.04.2019).

[45] Good Game 2. "What Makes a Good Game?" https://serc.carleton.edu/introgeo/games/goodgame.ht $\underline{\mathrm{ml}}(02.04 .2019)$.

[46] Wissner, M., Kistler, F., Andre, E. "Level of Detail AI for Virtual Characters in Games and Simulation". MIG 2010, LNCS 6459, pp. 206-217, 2010.

[47] Luebke, D., Reddy, M., Cohen, J., Varshney, A., Watson, B. and Huebner, R. "Level of Detail for 3D Graphics". Morgan Kaufmann, ISBN 1-55860-838-9.

[48] Choubik, Y., Mahmoudi, A. "Machine Learning for Real Time Poses Classification Using Kinect Skeleton Data". Conference: 2016 13th International Conference on Computer Graphics, Imaging and Visualization (CGiV), 2016.

[49] Bhattacharya, A, Czejdo, B., Perez, N, “Gesture classification with machine learning using Kinect sensor data". Third International Conference on Emerging Applications of Information Technology, 2012. 